\title{
FRANCISCO COLOANE AND THE DIPLOMATIC RELATIONS BETWEEN CHILE AND THE GERMAN DEMOCRATIC REPUBLIC ${ }^{1}$
}

\author{
Francisco Coloane y las relaciones diplomáticas entre Chile \\ y la República Democrática Alemana
}

\author{
Enrique Fernández*
}

\begin{abstract}
This article analyses the unknown contribution of the Chilean writer Francisco Coloane to the establishment of diplomatic relations between the German Democratic Republic and Chile in 1971.The article first reviews the international political conflicts between the two German states that took place after the Second World War and the relationship between the German Democratic Republic and Latin America, especially with Chile. Then, starting with a review of GDR archival material and the Chilean and German press during that time, the article rebuilds the relationship between Francisco Coloane and the

\footnotetext{
${ }^{1}$ This article was written in the framework of Fondecyt project 1140020, "Comunidades epistémicas internacionales. Formación de redes científicas chileno alemanas, 1950-2010”.

Este artículo fue enviado a revisión inicialmente en espańol y ha sido traducido al inglés gracias al Proyecto FP150008, "Aumento y mejora del índice de impacto y de la internacionalización de la revista Universum por medio de la publicación de un mayor número de artículos en inglés". Fondo de Publicación de Revistas Científicas 2015, Programa de Información Científica, Comisión Nacional de Investigación Científica y Tecnológica (Conicyt), Chile.

This paper was initially sent for review in Spanish, and it has been translated into English with the support of the Project FP150008, "Aumento y mejora del índice de impacto y de la internacionalización de la revista Universum por medio de la publicación de un mayor número de artículos en inglés." Fund for publication of Scientific Journals 2015, Scientific Information Program, Scientific and Technological Research National Commission (Conicyt), Chile.

* Universidad de Tarapacá. Arica, Chile. Correo electrónico: efernandezdarraz@gmail.com

Artículo recibido el 30 de junio de 2015. Aceptado el 16 de diciembre de 2015.
} 
German Democratic Republic. Finally, it analyzes the role Coloane played in promoting the image of the German Democratic Republic in Chile in the 1960s.

Keywords: International Relations, Hallstein Doctrine, GDR, Chile, Francisco Coloane.

\section{RESUMEN}

El artículo analiza la desconocida contribución del escritor Francisco Coloane al establecimiento de relaciones diplomáticas entre la República Democrática Alemana y Chile en el año 1971. Para ello revisa, primero, la disputa política internacional de ambas Alemanias con posterioridad a la Segunda Guerra Mundial y la relación de la RDA con América Latina y en especial con Chile. En seguida reconstruye la relación de Francisco Coloane con la Alemania Democrática, a partir de la revisión de material de archivo de ese país y de prensa chilena y alemana de la época. Por último analiza el rol que Coloane jugó, promoviendo la imagen de la RDA en Chile en la década de 1960.

Palabras clave: Relaciones Internacionales, Doctrina Hallstein, RDA, Chile, Francisco Coloane.

\section{INTRODUCTION}

In the year 1971, Chile became the first Latin American country to establish diplomatic relations with the German Democratic Republic (GDR), after Cuba, who initiated them in 1963.

Until that date, the other Germany, the Federal Republic of Germany (FRG) had achieved to impose the doctrine called Hallstein internationally, that consisted in claiming the rightful succession of the German empire and the representation of the German people. For that same reason, it was considered to be the only one of the both countries with the right to establish diplomatic relations with other states.

Before any intent by some nation to officially make ties with the GDR, the FRG immediately responded by expressing its inappropriateness and the inevitable consequences that it would have for their own bilateral relationships and in the cooperation of development.

The Democratic Germany, however, enjoyed a vast diplomatic insertion in the eastern bloc and developed intense activity dedicated achieving their recognition, just as much in Latin America as in Africa and Asia, through the development of relationships at a social, political, economic, and cultural level. Obviously, central actors of this effort were the Socialist Unity Party of Germany (SED) and the local communist parties.

In the intense exchange that took place between the GDR and Chile, some politicians and Chilean intellectuals played very important roles in the diffusion 
and support of the Democratic Germany. One of these was the known writer, National Literature Award (1964) winner, Francisco Coloane. Nonetheless, this aspect of his intellectual work has stayed, until now, practically ignored.

This article reconstructs this story by reviewing archival materials of the lost GDR and the press of that time, as much as Chilean as German. The first step reviews the dispute between both Germanys in international politics. Next, it analyses the insertion of the GDR in Latin America and Chile, and the strategies that it utilized to improve its position and image. Finally, it searches for the link between Francisco Coloane and the GDR and the role that he played as diffusor of the ideas and the way of life that that country embodied.

Even though the Chronicles of his "Trip through East Germany" are summarized and reviewed, it is not the purpose of this article to determine the literary worth or the place it corresponds to among his work, but to do archaeology on the relationship between a writer that already passed away and a country that now no longer exists and that in their moment yielded benefits for both of them.

\section{THE GDR AND THE HALLSTEIN DOCTRINE}

The end of World War II left Germany occupied by the winning powers: The United States of America, England, France, and the Soviet Union. The delineation of the occupied geographic zones, as well as their administrative regimen, was formalized in the Potsdam Conference that took place between the days July 17th and August 2nd, 1945. An equal territory division was also implemented in its said capital, Berlin, and its administration was left in charge to a "Allied Control Council", made of the high-ranking officials of the victorious militaries (Mählert, 2010: 19).

The agreements considered a joint-administration of the occupied zones and predicted a reunification of the country in the long term. However, the previous events led to the division of Germany into two big geographic units. One governed by the Allied forces and the other by the USSR.

The differences escalated to such a point that in May 1949 the German Constitution was enacted which would govern the western zones. On August 14th, the parliament was elected, and as of September 15th Konrad Adenauer was chosen as Chancellor (Schöllgen, 2013: 26-27). In the Soviet zone a popular parliament was tentatively constructed in May 1949, which enacted on this same day a constitution and named Wilhelm Pieck as Prime Minister. A day later, Otto Grotewohl became President of the GDR (Schöllgen, 2013: 30; Mählert, 2010: 53-55).

Upon arriving to the end of the 1940s, it was obvious that the old Germany had transformed into two distinct countries. Each one with its own government 
and aligned with one of the two sides of the Cold War. This fact unleashed an international fight between the two for reaching recognition as sovereign states.

In this context emerged what would be known afterwards as the Hallstein Doctrine $^{2}$. According to this doctrine, the FRG claimed to be the legitimate successor of the German empire and representation of the German people. As for the GDR, it was seen by them as a country subjected to the Soviet Union and for the same reason, without political sovereignty or right to establish diplomatic relations with other countries. Along with this, it must be added that their interest in accomplishing the reunification of Germany, its model of government and in alignment with the western powers ${ }^{3}$.

For these reasons, the FRG tried to systematically stop the Democratic Germany from obtaining political recognition beyond the eastern bloc, especially in the Third World countries and those called "not aligned". As a pressure mechanism, the threat to break their own diplomatic ties was utilized with states that wanted to establish relations with the GDR, as well as withholding their support for development.

The first conflict happened when Burma, in the middle of 1955, announced that it would match the status of the division of the GDR with that of the FRG, anticipating that it would establish diplomatic relations with the first. The response from Federal Germany was immediate: it informed the Minister of Foreign Affairs that this would be considered a hostile act and that it would have serious consequences, among them the end of diplomatic relations. This made the government of Burma not implement the measure (Kilian, 2001: 10-21).

From that moment onwards, the application of the doctrine would become stricter, despite that in each situation they would have to do an evaluation of the specifics steps to take.

Yugoslavia -in 1957-and Cuba-in 1963- were the first countries where the Hallstein Doctrine was applied. Three days after that, Marshal Josip Broz Tito publically informed about the establishment of diplomatic relations with the GDR, the Federal Germany put an end to those that had been initiated in 1951. The same occurred with Cuba six years later.

Africa was also on the scene during this diplomatic confrontation. As a product of the decolonization process, several new independent nationals states were arising and important liberation movements were happening, making the continent a favorable place for this dispute (Blumenau, 2011: 15).

The Arab world was involved in a similar way in this conflict. The habitual tensions of the dispute were exacerbated in 1964 by the discovery of the shipments

\footnotetext{
${ }^{2}$ The name is comes from Walter Hallstein, the secretary of the External Relations Minister.

${ }^{3}$ GDR and the URSS had an identical interest: to achieve German unification aligned with the soviet bloc.
} 
of weapons to Israel by the FRG. In response, the prime minister of the Democratic Germany was invited to visit Cairo. Federal Germany, in turn, reciprocated by establishing diplomatic relations with Israel on May 12th of that year. As a consequence, ten Arab countries broke relations with the country in the following four days (Kilian, 2001: 100-162).

Latin America did not stay in the margins of this dispute. An exemplary case occurred in 1961 when Brazil tried to become closer to the GDR. The FRG made it known that the said situation would be understood as recognition of the Democratic Germany and that that would have implications on the relations between both countries. As a result, Brazil did not pursue the invitation (Rebmann, 2010).

In summary, both Germanies deployed an intense international fight to achieve recognition as a sovereign state and legitimately represent the German nation.

\section{THE GDR AND LATIN AMERICA}

With the objective of achieving international recognition, the GDR developed a series of business, political, social, and cultural initiatives with distinct countries. They signed agreements, established chambers of commerce, created ties with political parties and social groups, developed activities on a cultural level, created Binational Institutes, and completed important aid projects and technology transfer.

The GDR implemented a scaling strategy in its international politics. This started with the signing of agreements that, in turn, would install business offices. Later, it would intend to make them consulates and afterwards, embassies (Blumenau, 2011: 14).

All of this work was accompanied by an intense "cultural diplomacy", which aimed to construct a favorable image of the GDR. This type of activity was focused on the concept of the era "cultural propaganda" and during the Cold War the two principal promoters were the USSR and the USA (Pedemonte, 2010: 60).

The relationships between the GDR and Latin America occurred within a true framework of recognition, starting with the establishment of commercial offices during the 50s (Krämer, 2011: 184-185). East Germany was signing agreements (in particular with banks) progressively with Uruguay and Argentina (1954), with Colombia and Chile (1955), and with Brazil (1958). Later, they opened commercial offices in those and other countries from the continent: Uruguay (1954), Colombia and Argentina (1955), and Brazil (1959) (Werz, 2011: 447-448).

The interest of the GDR in Latin America changed due to the Cuban Revolution in 1959. This marked a turning point in their foreign policy towards the region and transformed Cuba into their principal partner. 
Other countries considered strategic were Brazil and those that refrained from voting in favor of the expulsion of Cuba from the OEA, in the session that occurred in Punta del Este in April of 1962: Argentina, Bolivia, Chile, Ecuador, and Mexico, even though the last country voted against it. The goal of making Brazil the pillar from where the GDR would work was complicated as a consequence of the military coup in 1964 (Krämer, 2011: 185-186).

Relationships with Chile, however, continued to increase. Among other reasons, for the calculation that the GDR did in respect to the possibility of finding support in the active Germanophile Chilean-German resident community and for the favorable political turn towards leftist ideas that the country was experiencing and that was expressed in a wide diplomatic receptiveness towards socialists countries (Pedemonte, 2010: 70-71).

Also, it was considered relevant that Chile had a Communist Party that was well-organized and "trustworthy" (Emmerling, 2013: 45).

Unfortunately, no literature exists that analyzes the cultural relationships between the GDR and Chile in an exhaustive manner. For the same reason, the characterization done only seeks to illustrate the central elements of the said relationship. For that, besides secondary literature, sources of Chilean and German press records of that time were used.

\section{THE GDR AND CHILE IN THE 1960s}

The relationship between the GDR and Chile began in 1952 when it was defined as a key for obtaining prime materials and for expanding commercial exchange. For this reason, the Ministry of Foreign and Internal Commerce sent a delegate to Chile in 1954, and the following year founded a commercial offices in Santiago (Dufner, 2007: 29-30). The low trade exchanges -among other considerations- led it to its closure in the years 1956/74 (Dufner, 2007: 32-33). Despite that, Chile continued being considered strategic (Dufner, 2007: 32-36) ${ }^{5}$.

The contacts between the PSUA and the communist party (CP) had been established at the beginnings of the 60s, with the visit to Chile by the person in charge of the trades of the PSUA and socialist countries. Later-this same yearsix militants of the CP traveled to East Germany (Emmerling, 2013: 69). In

\footnotetext{
${ }^{4}$ The closing date is inaccurate, but it is estimated that it occurred in 1956 or 1957 . The closure of the division was also associated to a scandal provoked by the offer that a Chilean politician made to the officials of the GDR to establish diplomatic relations in exchange for money (Dufner, 2007: 32). ${ }^{5}$ Towards the middle of the 1960s, the GDR kept with this strategic character with only three Latin American countries: Cuba, Chile and Uruguay (Emmerling, 2013: 91).
} 
October, the first delegations of Chilean parliamentarians landed in the GDR and in February of 1961, two German officials that gave humanitarian aid for those affected by the earthquake visited national territory (Emmerling, 2013: 72-73).

This type of exchange continued during the whole decade. In 1965, for example, the Chilean parliamentarians made a second visit to the GDR (Emmerling, 2013: 100) and the following year another group traveled to the city of Dresden (El Siglo 03.11.66: 11).

Product of these relationships and of the visit in 1965 by the Ministry of Foreign Affairs officials of the GDR, Democratic Germany reopened their representation in 1966 (Dufner, 2007: 37-38).

In the social and especially in the cultural area, the ties developed were also very intense. Since 1961, in Santiago there has existed a Chilean-Democratic German Culture Institute (Kulturinstitut Chile-DDR) (BArch DY/30/IV A 2/20 726:4)6.

The institute developed intense activity and through that an important link was established with the political scene. Moreover, their directory was composed of five Chilean senators (Emmerling, 2013: 99). Towards 1967, the Institute had two radial programs (in Radio Magallanes and in the Radio of the State Technical University), some 170 students in German language classes and headquarters in five cities: Arica, Antofagasta, Valparaíso, Concepción, and Temuco (El Siglo 05.10.67:4). In May of 1969, with the help of the institute, a committee was formed to organize the "First Conference of the Friends of the GDR in Chile", formed by diverse personalities, among them senators, deputies, mayors, artists, and writers. Among these last ones mentioned included Pablo Neruda and Juvencio Valle (BArch DY/30/IV A 2/20 726:116; Emmerling, 2013: 104).

In the year 1962, a group of climbers from the GDR visited the country in response to an invitation that the Federation of Climbing and Hiking of Chile sent (Emmerling, 2013: 75). In that year a union delegate from the GDR traveled to Chile with the motive of the III Conference of the Workers' Central Union (CUT). The professor Manfred Kossok, of the University of Leipzig, conducted a series of lectures in that context (Emmerling, 2013: 76).

Also, in the journalism sector several exchanges were made: in the year 1965 "El Siglo" newspaper sent to Eastern Berlin a reporter and an official from the German General Service of News arrived to Chile (Möbus, 2005: 36; Dufner, 2007: 55).

In the year 1966, the same newspaper reported that young Germans visiting Chile in the context of the Youth Communist Conference had delivered medical supplies to the community called "22 de Julio" (El Siglo 07.02.66: 5).

\footnotetext{
${ }^{6}$ There is no certainty about the founding date, but there is information that in 1959 it had already started activities (Emmerling, 2013: 95).
} 
The already mentioned visit of professor Kossok in the year 1962 established the beginning of the collaboration at a university level. Two years later, it was signed between the University Carlos Marx of Leipzig and the "Universidad Nacional de Santiago de Chile". Later, on in the year 1966, an agreement was also signed between the State Technical University and the Technical University of Dresden (El Siglo 06.10.66:7; El Siglo 05.10.67: 4).

The year 1966 was also marked by an important artistic and cultural activity. In July, the Bach Orchestra performed in Chile, coming from Leipzig ( $E l$ Siglo 22.07.66: 10). That year, "Silvia Infanta y Los Cóndores" did a tour through Europe that started in GDR (El Siglo 13.11.66:22). Their trip and presentations were financed by the "Central Agency of Artists of the German Democratic Republic" (El Siglo 22.03.66: 8).

The press also mentioned the presence of the Chilean pianist Oscar Gacitúa in the GDR, who in 1966 did a total of 11 performances (El Siglo 31.01.67: 9).

The Chilean soccer team visited Eastern Germany that year to play against its local equivalent. Prominent player Elías Figueroa in an interview talked about the great hospitality they received (El Siglo 05.10.67: 10).

A topic less known but also relevant was tourism, which was developed in a significant way in the era. For example, in the commemoration of the 50th anniversary of the Russian Revolution more than 700 Chilean tourists visited the Soviet Union (Pedemonte, 2011: 78). Of them, three groups between 120 and 150 people also visited the GDR (BArch DY/30/IV A 2/20 726: 64).

One of the moments that held great importance in the political and cultural binational relations was the anniversary of the GDR. With this motive distinct events happened, the Chilean-Democratic Germany Institute of Culture acting like a host and organizer of the celebrations.

\section{FRANCISCO COLOANE Y HIS TIES WITH GERMAN DEMOCRATIC REPUBLIC}

Despite what happened on his other trips, it is not easy to establish the origin of the relationship of Francisco Coloane with the GDR since he didn't leave a testimony about it in his autobiographies nor about the two visits he made in that country. This is curious since in several different passages of distinct texts he mentions his trips to the Soviet Union, China, Mongolia, India, among others (Vidal, 1991; Coloane, 2000).

It was only possible to find a personal reference to his relationship with the GDR in an interview for the newspaper La Tercera in the year 2000. There exists, additionally, four letters that he sent in 1965 from that country, published 
in the posthumous book that compiled the correspondence to his wife, but poorly contributes to the limited existing information.

In the interview he explains the way in which he arrived to West Germany. However, in addition to retaining certain inaccuracies, does not give major details:

Do you know when I changed my perspective about men? I can tell you: I was invited to Germany in the year 1966 and 1967. In Chile, I met a German professor, curious thing that came to Chile escaping Nazism [...]. When the war ended he went back to Berlin where he retook his Spanish course. He invited me to Germany. As it became a formality in those years, you have to visit the concentration camps, and I, even though it hurt me, I said Auschwitz. The professor didn't want to come with me and said: 'Coloane, I'm sorry, but I lost my family there' [...]. (http://www.letras.s5.com/coloane2.html).

There are two inaccuracies contained in the text. First, he refers to the years: 1966 and 1967, since his trips to the GDR took place in 1965 and 1966. Second, he refers to Auschwitz. The German press does not register his visit at the said concentration camp, but at that of Buchenwald, in the setting of the writers' meeting of 1965 (Berliner Zeitung 20.05.65: 3). Additionally, in one of his letters to his wife he would tell her that he went to that concentration camp and that Eduardo Klein, the German mentioned in the interview, excused himself from accompanying him (Coloane, 2005: 164).

The first time that the West German newspapers made mention of Francisco Coloane was in October of 1964, with the motive of the 15th anniversary of the GDR. In Santiago there was a commemorative act organized by the ChileanDemocratic German Culture Institute, in which diverse personalities of the "political and cultural life" participated, among them mentioned is Francisco Coloane, highlighting that in that year he had obtained the National Literature Award (Neues Deutschland 10.10.64: 5).

In 1965, between the 14th and 22nd of May, the International Writer's Conference took place in Berlin and Weimar. 190 delegates from 52 countries participate in it, and among those one would find the Chileans Pablo Neruda and Francisco Coloane (Schidlowsky, 2008:1131-1132; Berliner Zeitung 22.05.65: 3). During the conference he took part in different programmed activities, including a brief speech he did in an event that occurred in the city of Weimar (Berliner Zeitung 20.05.65: 3) ${ }^{7}$. Additionally, he was photographed in conversation with other writers (Neue Zeit 20.05.65: 1; Berliner Zeitung 26.05.65: 6).

\footnotetext{
7 This statement -same as Pablo Neruda's- was completely printed in the protocol of the Writers Conference that was published by the German Society of Writers of Berlin in 1965 (DSV 1965: 102-104).
} 
He will reappear in the German press in August of that year. He is mentioned because of two interviews that he gave upon his return from the GDR, one on the radio for the State Technical University and the other for the University of Chile's television channel. In both he referred to Democratic Germany and shared about his stay there (Berliner Zeitung 02.08.65:2). In November of the same year, he was interviewed in Santiago by the reporters of the newspaper Neues Deutschland and by German television (Neues Deutschland 25.11.65: 4).

Everything indicates that for that date, the relationship of Francisco Coloane with the GDR had become intimate and he regularly collaborated with the Chilean-Democratic German Culture Institute. For example, leading conferences like the one held in May of 1966 entitled "Germans in Chile" (El Siglo 15.05.66: 5).

That same year Coloane stayed more than two months in Democratic Germany, invited by the Association of Writers of the German Democratic Republic (Última Hora 27.06.66: 5).

In a letter dated May 27th, addressed from Gerhard Henninger (First Secretary of the Association of Writers of the GDR) to Kurt Hager (a professor from the University of Humboldt and member of the central committee of the PSUA), notifying about the writer's next visit to the country. In it he requested that he give him the most complete vision possible of the life in West Germany, considering that Coloane had intended to publish a book about the GDR. Furthermore, he stated that during his stay he would regularly publish chronicles in the Chilean newspaper "Noticias de Última Hora" (DY/30/IV A 2/20 726: 47).

Indeed, during his time in the GDR Coloane wrote a series of articles that were titled "Trip to East Germany" and were published in the newspaper "Última Hora". The first of his thirteen chronicles appeared Monday, June 27th and the last Thursday, September 1st. Additionally, he published in the newspaper El Siglo Sunday, July 3rd, $1966^{8}$.

His visit was occasionally followed by the German press. In one instance they announced his arrival to the GDR (Neues Deutschland 16.06.66: 5) and later disclosed a note about the purpose of his trip to the coast where he met with the high seas fishermen (Neues Deutschland 30.07.66: 10).

According to the reporter from the newspaper El Siglo, Francisco Coloane could have left the GDR after a 3 month stay, which allows the assumption that he could have stayed there until the beginning of September (El Siglo 27.09.66: 7).

\footnotetext{
${ }^{8}$ In a conversation with Juan Francisco Coloane, son of the writer, in Santiago, October 22nd 2014, he confirmed the existence of these chronicles and estimated its length to be about 80 pages. Unfortunately, it was not possible to access to the mentioned documents since they have not been published yet.
} 
In 1967, Coloane held a central role in the anniversary of the GDR in Santiago, inaugurating the festivities with a presentation titled "New Brandenburg and Germanic Myths" (El Siglo 02.10.67: 4). This was partially published in the newspaper El Siglo, and according to the report by the Press Department of the GDR, the text additionally had been printed in full (El Siglo 08.10.67:9; BArch DY/30/IV A 2/20 726: 86) ${ }^{9}$.

From that year onwards, it is not possible to establish a continuity in the relationship between Francisco Coloane and the GDR. He reappears in the press in July of 1969 in the setting of a meeting planned by "Círculo de Amigos de la RDA", that assembled more than 300 participants (among them was the senator Salvador Allende) and that culminated with an appeal to the Chilean government to establish diplomatic relations with East Germany (Neues Deutschland 22.07.69: 7) ${ }^{10}$.

By that date, however, Francisco Coloane had already fulfilled a relevant role in the relationship with the GDR, spreading aspects of the life in that country and promoting the establishment of diplomatic relations with them.

It's this context that makes the explication that the writer himself gives in La Tercera about his arrival in Germany does not prove very plausible; not because it's false, but incomplete. It seems much more plausible that Francisco Coloane had been invited as part of a job for cultural propaganda that the GDR did and that they found in him a representative that fulfilled three important conditions: he was an activist of the Communist Party and, for the same reason, someone trustworthy; he shared the cause of the GDR and would publicly defend it; also, he was a well-known writer, whose opinion was relevant in Chilean society.

It's not possible, drawing from the found documentation, to identify the motivation that Coloane himself had for traveling to the GDR and promoting his international presence. It can only be speculated with a combination of similar factors: it proved to be a valuable cause for him, he knew his voice would be heard and additionally, he would take advantage of traveling to know their reality.

In summary, this was a relationship that yielded mutual benefits in the framework of an aligned ideological relationship.

\footnotetext{
${ }^{9}$ Unfortunately, it was not possible to find this document in all the files reviewed. Neither Juan Francisco Coloane could confirm that this was present in a family file.

${ }^{10}$ In the year 1972 a tale of Coloane was published that was translated to German as "Nocturnal camp at the Pampa" (Neue Zeit 19.02.72: 8). After that his figure was not present anymore in the GDR press.
} 


\section{COLOANE Y HIS “TRIP TO EAST GERMANY”}

During his stay in the GDR in the year 1966, Francisco Coloane published 13 chronicles in the newspaper Última Hora and one in El Siglo. These probably would have formed the book he had intended to publish, as he pointed out to the press, it wouldn't have "philosophical or ideological claims," but would try to be an objective account (El Siglo 27.09.66: 7).

The chronicles of Coloane corresponded to brief texts about his insights on the life in GDR, which regularly appeared in the Chilean press. Only two of these escaped the narrative format and general theme. One about the ITUCH, the Theatre Institute at the University of Chile (Última Hora, 06.07.66: 14) and the other published in El Siglo, that corresponds to a long conversation with the writer Gerhard Engler (El Siglo 03.07.66: 7).

Table 1.

\section{Chronicles about the GDR from Francisco Coloane in the Chilean press in 1966}

\begin{tabular}{|l|l|l|l|}
\hline $\mathbf{N o}$ & Chronicle & Newspaper & Date and Page \\
\hline 1 & "First hours in Berlin" & Última Hora & Monday, June 27th, p. 5 \\
\hline 2 & "With the German worker" & Última Hora & Friday, July 1st, p. 14 \\
\hline 3 & "The German way to socialism" & El Siglo & Sunday, July 3rd, p. 7 \\
\hline 4 & "By the Schwielow lake" & Última Hora & Tuesday, July 5th, p. 14 \\
\hline 5 & "Tribute to ITUCH" & Última Hora & Wednesday, July 6th, p. 14 \\
\hline 6 & "Beethoven" & Última Hora & Sunday, July 10th, p. 11 \\
\hline 7 & "New Brandenburg" & Última Hora & Thursday, July 28th, p. 5 \\
\hline 8 & "The New Brandenburg & Última Hora & Sunday, July 31st, p. 5 \\
\hline 9 & "Stralsund" & & \\
\hline 10 & "In Rügen's Island" & Última Hora & Thursday, August 4th, p. 5 \\
\hline 11 & "Pay for their crimes" & Última Hora & Tuesday, August 9th, p. 5 \\
\hline 12 & "Reynolds Brummack's opinions" & Última Hora & Sunday, August 21st, p. 14 \\
\hline 13 & "The Hiddensee Island" & Última Hora & Wednesday, August 24th, p. 5 \\
\hline 14 & "The capitans of the harvest" & Última Hora & Thursday, August 26th, p. 5 \\
\hline
\end{tabular}

Source: Diario Última Hora, Diario El Siglo.

Just as he had proposed it, Coloane tried to act "like a mirror that walks along a path... "(El Siglo 27.09.66: 7), for the same reason, his stories are mainly descriptive, narrating his impressions and experiences in that country in the most realistic way possible. 
His stories talk about daily life, they are visits to factories, farms, towns; they contain conversations with workers, with authorities and local politicians, and with neighbors. They are filled with descriptions of natural landscapes and humans, of work conditions, and the life of the people. They highlight in a barely explicit way the possibilities to construct socialism and, in general, a fairer society.

Many passages do not have the tidiness like the majority of his literature, which is surely due to the character of the written works and to the time pressure with which they were composed.

Through his chronicles, and perhaps without proposing it himself, Coloane contributed in a very notable way to the proposals for recognizing the GDR internationally, since they transmitted not only the fact that socialist ideals were embodied in a society, but that it also existed as an independent nation.

The only occasion in which the writer went explicitly beyond his mere descriptive will is when he praised the kindness of socialism and stated the need to establish diplomatic relations with them, which was during the 18th anniversary of the GDR. In the conference that he led in Santiago, he would ask himself:

Why do the German socialists have milk in abundance, considering these prime materials are torn from our oceans, while we lack meat and milk? I cannot explain it to myself and I leave it for your reflection. Why do we supply fishmeal to the GDR and we do not have diplomatic relations with them? Also, another motive for reflection. (El Siglo 08.10.67: 9).

\section{CONCLUSIONS}

The division of the German empire into two ideologically incompatible countries was not just one of the consequences of the Second World War, but one of the most concrete examples of the scale that the Cold War reached.

While the Democratic Germany tried to achieve international recognition as a nation beyond the eastern bloc, their Federal counterpart was trying to stop it. In pursuit of this, both Germanys displayed all their diplomatic, political and economic power.

One of the "weapons" which both countries -and in general both blocsappealed was "cultural propaganda". Also, in this sense, there was a correlation with the arms race of that time.

It's in this context that the figure of Francisco Coloane was linked with Democratic Germany. His communist militancy, his favorable vision towards socialism and his literary prestige transformed him into an ideal candidate to argue for its diplomatic recognition. For him -a lover of traveling- his stays in this country, especially the second one, must have been an adventure that he could not refuse. 
During his permanence in the GDR and especially when he came back, Coloane wrote and spoke about it with endless enthusiasm. He described in simple prose the every-day life of its people and, through this, the achievements of the political project normally devalued by many.

In this way, in the middle of the Cold War, Francisco Coloane became a sort of cultural ambassador of the GDR that not only promoted its image, but also fought for its recognition as a nation. This was not in the political decisions area, but in a more relevant and transcendent way: opening everyone's eyes that it was not reasonable to continue denying its existence itself.

\section{REFERENCES}

Blumenau, Berhard. The Map of Africa. Lies in Germany: The Two Germanys and their Struggles for Recognition in Africa. Geneve: Department of International History. Graduate Institut of International and Development Studies, 2011.

Coloane, Francisco. Memorias. Los pasos del hombre. Barcelona: Mondadori, 2000.

Coloane, Francisco. Papeles Recortados. Santiago, Chile: LOM Ediciones, 2004.

Coloane, Francisco. Última carta. Santiago, Chile: Editorial Universidad de Santiago, 2005.

Deutscher Schriftstellerverband Berlin (DSV) (ed.). Internationales Schriftstellertreffen Berlin und Weimar 14.-22- Mai 1965. Protokoll. BerlinWeimar: Deutscher Schriftstellerverband Berlin, 1965.

Dufner, Georg. Chile als Bestandteil des revolutionären Weltprozesses. Die Chilepolitik der DDR im Spannungsfeld von außenpolitischen, ökonomischen und ideologischen Interessen 1952-1973. Tesis de Magíster. Universidad Humboldt: Berlin, 2007.

Emmerling, Inga. Die DDR und Chile (1960-1989). Aussenpolitik, Aussenhandel und Solidarität. Berlín: C. H. Links, 2013.

Gray, William Glenn. German's cold war. The global campaign to isolate East Germany, 1949-1969. Chapel Hill: University of North Carolina Press, 2003. 
Kilian, Werner. Die Hallstein-Doktrin. Derdiplomatische Kriegzwischen der BRD und der DDR 1955-1973: aus den Akten der beiden deutschen Aussenministerien. Berlín: Duncker \& Humblot, 2001.

Krämer, Raimund. "De una diplomacia desaparecida. La política exterior de la República Democrática Alemana y sus relaciones con América Latina", Estudios internacionales 28/110 (2011): 174-197.

Mählert, Ulrich. Kleine Geschichte der DDR. München: C. H. Beck, 2010.

Möbus, Karlheinz. "Die DDR und Chile Entdecken sich". In Gotthold Schramm (Ed.), Flucht vor der Junta. Die DDR und der 11. September. Berlín: Edition Ost, (2005): 33-45.

Pedemonte, Rafael. "La 'diplomacia cultural' soviética en Chile (1964-1973)", Bicentenario. Revista de Historia de Chile y América 9/1 (2010): 57-100.

Rebmann, Linda. "La política alemana de cooperación para el desarrollo en la época de la Doctrina Hallstein y su incidencia en las relaciones con Brasil", Ciclos XIX/37-38 (2010): 137-160.

Schidlowsky, David. Neruda y su tiempo: 1950-1973. Santiago, Chile: RIL Editores, 2008.

Schöllgen, Gregor. Deutsche Außenpolitik. München: C. H. Beck, 2013.

Vidal, Virginia. Testimonios de Francisco Coloane. Santiago, Chile: Ed. Universitaria, 1991.

Werz, Nikolaus. "Hinter der Mauer - Lateinamerika in der DDR". Die DDR eine deutsche Geschichte. Wirkung und Wahrnehmung. In Detlef Brunner \& Mario Niemann (Eds.), Schöningh: Paderborn, (2011): 445-464. 


\section{ARCHIVED MATERIAL}

Bundesarchiv: Institut für Marxismus-Leninismus beim ZK der SED. BArch, DY/30/IV A2/9.07.

Bundesarchiv: Internationale Verbindungen. BArch, DY/30/IV A2/20 726.

\section{PRESS}

El Siglo

Última Hora

Berliner Zeitung

Neue Zeit

Neues Deutschland

\section{OTHER SOURCES}

www.letras.s5.com

www.memoriachilena.cl 